\title{
2018 Real Estate Finance \& Investment Symposium
}

\author{
Thies Lindenthal ${ }^{1}$ (D) David C. Ling ${ }^{2} \cdot$ Joseph Ooi ${ }^{3}$
}

Accepted: 10 January 2022 / Published online: 19 January 2022

(c) The Author(s) 2022

\begin{abstract}
In October 2018, the Real Estate Finance \& Investment Symposium, sponsored and organized by the University of Cambridge, the University of Florida, and the National University of Singapore, was held in Gainesville, Florida. Ten papers on various research topics were presented over the day and one-half symposium. Each presentationwas followed by remarks from a discussant as well as general discussion from the audience. This short editorial discusses the five papers from the symposium that are included in this special issue.
\end{abstract}

Keywords Real Estate Finance $\cdot$ Real Estate Investments

In October 2018, the Real Estate Finance \& Investment Symposium, sponsored and organized by the University of Cambridge, the University of Florida, and the National University of Singapore, was held in Gainesville, Florida. Ten papers on various research topics were presented over the day and one-half symposium. Each presentation was followed by remarks from a discussant as well as general discussion from the audience. Five papers from the symposium are included in this special issue. Three of these papers are focused on commercial real estate; two on the housing market. The remainder of this introduction briefly describes the papers included in this issue.

The ability to sell assets quickly at full value is crucial in any investment asset class. But how does liquidity "happen" in the private property market and what are

\footnotetext{
Thies Lindenthal

ht124@cam.ac.uk

David C. Ling

david.ling@warrington.ufl.edu

Joseph Ooi

joseph.ooi@nus.edu.sg

1 Department of Land Economy, University of Cambridge, Cambridge, UK

2 Bergstrom Real Estate Center, University of Florida, Gainesville, FL, USA

3 Department of Real Estate, National University of Singapore, Singapore, Singapore
} 
the underlying dynamics of liquidity? Liquidity is, of course, co-determined with prices-it is easier to sell an asset more quickly for a lower price. The analytic construct of the "constant liquidity value" index developed by Fisher et al. (2003) essentially collapsed the price and volume dimensions of the property market onto a single price dimension based on the demand side of the market. The paper's idea is that a constant liquidity index presents a more complete picture of the property market and a more useful metric for quantitative comparisons of private commercial real estate assets to "constantly liquid" public securities. In "The Dynamics of Liquidity in Commercial Property Markets: Revisiting Supply and Demand Indexes in Real Estate," Dorinth van Dijk, David Geltner, and Alex van de Minne extend the Fisher et al. (2003) methodology to a repeat sales indexing framework. They estimate their model using data provided by Real Capital Analytics (RCA). The authors find that supply tends to move slower than demand, perhaps due to anchoring and loss aversion and issues related to mortgage debt. The transaction price index that is usually estimated in a repeat sales framework also lags behind the reservation prices of buyers.

Additionally, van Dijk, Geltner, and van de Minne examine a liquidity metric based on the difference between buyers' and sellers' reservation price indexes. They document that markets typically display pro-cyclical variable liquidity; that is, price and volume moving together. However, in approximately a third of the calendar quarters in their sample the authors find that liquidity declined while prices were rising. Moreover, this anomaly often predicts declining asset prices. The authors suggest this may be evidence that buyers become "exhausted" or wary of recent price increases.

The real estate investment literature has treated the option to improve assets with invest capital expenditures (CAPEX) and the decision to sell an asset independently. In "Economic Fundamentals, Capital Expenditures and Asset Dispositions," Brent Ambrose and Eva Steiner show that the two options are interconnected. Modelling investment in CAPEX as a real option to improve an asset that has suffered physical depreciation and economic obsolescence, they find that higher CAPEX spending reduces the likelihood of sale. The paper provides empirical evidence that property owners increase CAPEX spending during periods of higher expected income growth (which increases the return on CAPEX investments). By contrast, owners reduce CAPEX spending during periods in which income growth expectations are volatile because the value of retaining the option to refurbish the property in the future is higher. In addition, Ambrose and Steiner provide evidence that CAPEX investments are only partially capitalized into asset values. The marginal economic effect of CAPEX on market values is larger during recessions than during expansionary periods, likely reflecting that investors only carry out the most profitable CAPEX projects under adverse economic conditions. Consistent with a value-add investment strategy, they also find evidence that the past performance of the property influences CAPEX expenditures but not disposition choices.

In "Social Capital and Mortgage Delinquency," Lingxiao Li, Erdem Ucar, and Abdullah Yavas develop a theoretical model to address the impact of "social capital" on mortgage delinquency. The authors define social capital as the "norms, values, trust, and information common to a social network, which enable cooperative and 
shared actions." Using a U.S. county-level data from 1999-2011, the authors present empirical evidence that social capital predicts mortgage delinquencies. The primary explanation offered by the authors is that social capital reduces opportunistic behavior among homeowners including strategic default. They also find an increase in the importance of social capital after the financial crisis of the mid-to-late 2000s. Overall, the authors' findings suggest that cooperative and shared actions, in addition to the factors already documented in the literature, play an important role in the household's default decisions.

Richard Keely and Ronan Lyons offer new evidence on residential prices, rents and yields in the long run. Their paper "Housing Prices, Yields and Credit Conditions in Dublin since 1945" first collects over one million sale and rental listings for the Irish capital Dublin, reaching back more than 70 years. The extensive data work pays off in two ways, at least: First, they can estimate price and rent indices a consistent way, using hedonic techniques to account for quality differences between the houses in their sample. Earlier work on real estate yields often relied on price and rent estimates from a variety of samples, with varying definitions and index estimation techniques. Here, nominator and denominator in the yield calculations are truly comparable. It comes as no surprise that the resulting gross yield estimates deviate significantly from earlier figures and are consistent with recent long-term yield estimates from other European cities. Second, the sample is large enough for sub-market comparisons. Dublin might be a small market compared to other cities in Europe or the world. Still, its dynamism is exceptional, both at the market and the submarket level. The study shows that rents converged within the city while sale prices have diverged over the same period. Resulting yields depend on conditions in the credit market and on user cost changes, as an error-correction analysis shows.

A large and growing literature has focused on understanding the behavior of economic agents and the roles they play in shaping investment decisions and asset values through their collective actions. Such behavior under various economic environments is difficult to examine because outcomes may vary for different types of agents at different stages of economic cycles. In "Asymmetric Patterns and Effects on Demand-Supply Mismatch," Gianluca Marcato and Anupam Nanda examine various indicators of demand-supply imbalances and their relationship to the dynamics of price determination in the commercial real estate market. Their theoretical hypotheses are based on the possibility of shifts in bargaining power and heterogeneous signal processing by buyers and sellers that can lead to a diverse range of buy/sell decisions and asymmetric adjustments in reservation prices. The period of analysis allows the authors to observe market dynamics over two economic cycles. Their empirical framework uses a range of indicators of investment attitudes and market expectations, such as marketing time, buy-sell recommendations, investment conditions, and measures of financial distress, to explain asymmetry in reservation price adjustments using a panel VAR approach. The authors' primary results suggest strong and statistically significant feedback effects from these indicators to asset prices. They also find evidence of asymmetric responses during boom, normal, and recessionary periods. The demand-supply mismatch and indicators of market expectations appear to exert more influence during down cycles than up cycles, which the authors attribute to a greater level of cautiousness by both buyers and sellers during down cycles. 
Open Access This article is licensed under a Creative Commons Attribution 4.0 International License, which permits use, sharing, adaptation, distribution and reproduction in any medium or format, as long as you give appropriate credit to the original author(s) and the source, provide a link to the Creative Commons licence, and indicate if changes were made. The images or other third party material in this article are included in the article's Creative Commons licence, unless indicated otherwise in a credit line to the material. If material is not included in the article's Creative Commons licence and your intended use is not permitted by statutory regulation or exceeds the permitted use, you will need to obtain permission directly from the copyright holder. To view a copy of this licence, visit http://creativecommons.org/licen ses/by/4.0/.

\section{Reference}

Fisher, J., Gatzlaf, D., Geltner, D., \& Haurin, D. (2003). Controlling for the impact of variable liquidity in commercial real estate price indices. Real Estate Economics, 31(2), 269-303.

Publisher's Note Springer Nature remains neutral with regard to jurisdictional claims in published maps and institutional affiliations. 